\title{
Trends in public spending on basic education compared to the quality of education in Mexico
}

\section{Tendencias del gasto público en educación básica en comparación con la calidad educativa en México}

\author{
VILLAFAÑA-INFANTE, Luz María de Guadalupe †*, ISLAS-GONZÁLEZ, José Antonio and \\ JIMÉNEZ-RICO, Artemio
}

Universidad de Guanajuato, Economic-Administrative Sciences Division, Guanajuato, Guanajuato, Mexico.

ID $1^{\text {st }}$ Author: Luz María de Guadalupe, Villafaña-Infante / ORC ID: 0000-0002-2695-7826, Researcher ID Thomson: AAL-7096-2021, CVU CONACYT ID: 1051002

ID $1^{\text {st }}$ Co-author: José Antonio, Islas-González / ORC ID: 0000-0002-9319-171X, Researcher ID Thomson: AAL-70742021, CVU CONACYT ID: 1129032

ID $2^{\text {nd }}$ Co-author: Artemio, Jiménez-Rico / ORC ID: 0000-0001-9069-6483, Researcher ID Thomson: S-7880-2018, CVU CONACYT ID: 947479

\begin{abstract}
Education is an indispensable public service for the country's development. In order to have access to quality education, more must be invested, especially in basic education, since it is the basis for educational development; however, not as much is invested compared to other OECD countries. In recent years, the basic education budget as a percentage of GDP has shown a downward trend from $2.3 \%$ to $1.9 \%$. Similarly, in the results of the last PISA test, Mexicans were positioned below the average, reflecting low performance compared to the OECD average. The objective of this research is to analyze whether public spending on basic education in Mexico has an impact on the quality of education at this level, measured in terms of the PISA test. It is also based on the trend method to analyze variations in spending. This contributes to the fact that due to the decreasing trend of the indicators, the competent authorities in Mexico design new policies that meet the needs of the new generations and lead to an increase in the performance of young Mexicans and increase the degree of educational quality in basic education.
\end{abstract}

\begin{abstract}
Resumen
La educación es un servicio público indispensable para el desarrollo del país. Para tener acceso a educación de calidad se debe invertir más, especialmente en la educación básica ya que es la base del desarrollo educativo, sin embargo, no se invierte tanto comparado con otros países de la OCDE. En los últimos años, el presupuesto en educación básica como porcentaje del PIB ha registrado una tendencia decreciente pasando de $2.3 \%$ a $1.9 \%$. Asimismo, en el resultado de la última prueba PISA, los mexicanos se posicionaron por debajo de la media reflejando bajo rendimiento comparado con el promedio de la OCDE. El objetivo de esta investigación es analizar si el gasto público en educación básica en México tiene un impacto en la calidad educativa de este nivel, medida en términos de la prueba PISA. Asimismo, está sustentada en el método de tendencias para analizar las variaciones del gasto. Esto contribuye a que derivado de la tendencia de decrecimiento de los indicadores, las autoridades competentes en México diseñen nuevas políticas que satisfagan las necesidades de las nuevas generaciones y que deriven en el aumento del desempeño de los jóvenes mexicanos y aumentar el grado de calidad educativa en la educación básica.
\end{abstract}

Gasto educativo, Calidad educativa, PIS

\footnotetext{
* Correspondence to Author (Email: lmdg.villafanainfante@ugto.mx)

$\uparrow$ Researcher contributing as first author.
} 


\section{Introduction}

Education is a very important factor in the development of any country, since it is the means by which the fundamental tools and knowledge that a professional must develop in order to improve the quality of life of the country are obtained, especially basic education, which is the one that sows the first bases of all the knowledge that will be developed through the following educational stages. However, in Mexico it is not equivalent to other countries of the Organization for Economic Cooperation and Development (OECD), that is to say, it does not invest as much in education as other countries do.

According to OECD data (2020a) during the last few years Mexico has had reductions in the budgets allocated to basic education causing us to go from a public expenditure of $2.9 \%$ with respect to GDP in 2012 to $2.4 \%$ of GDP for 2017, a figure that barely equals the general OECD average of $2.4 \%$ of GDP for basic education. However, when the comparison of per capita GDP education expenditure is made, for 2017 Mexico presents 14\% and 12\% per pupil, for primary and secondary respectively, far below the $21 \%$ and $24 \%$, respectively, presented by the OECD average.

The above shows that although Mexico invests the same amount of GDP as the OECD in basic education, this is not enough, since it is not proportional to the increase in the population of students in the country, and this, together with the constant reductions in the education budget, could affect the results of basic education performance in future scenarios.

On the other hand, in recent performance evaluations, Mexico has increased its scores in the PISA test, however, these are still well below the OECD average.

The objective of this research is to analyze whether public spending on basic education in Mexico has an impact on the quality of education at this level, measured in terms of the results obtained in the PISA test.

This research is based on the trend method to analyze the variations in spending on basic education, in order to contrast it with the progress in quality that has been made in recent years.
Likewise, a comparison is made with OECD countries to identify the gaps that exist in public spending on education.

\section{Literature review}

\section{Educational Spending}

According to the Center for Economic and Budgetary Research (CIEP) "educational spending is understood as the sum of the total of the education function and that allocated to the Ministry of Public Education (SEP) through functions other than education" (Martínez, 2020, p. 1).

On the other hand, García (2016) states that educational spending in Mexico is constituted on a programmatic basis, in which four main classifications can be identified: economic, administrative, functionalprogrammatic and geographic, which are grouped according to their nature and purpose. The administrative classification seeks to answer the question "How are the resources allocated to public education used? Two other types are derived from this classification: current spending, which refers to activities that do not seek a lucrative purpose but rather an act of consumption; capital spending, which refers to expenditures for the creation of capital goods and the conservation of those that already exist, in order to generate and conserve the country's physical or financial assets. On the other hand, the administrative classification is that which seeks to answer who spends the resources destined to public education? With this classification it is possible to identify what percentage of public spending is allocated to the states and municipalities, the SEP, and the other institutions that make up the National Education System (SEN). In turn, the geographic classification identifies the territorial location where public resources are spent, that is, this classification allows us to identify the percentage of public spending that is allocated to each of the states and municipalities that make up the Mexican Republic. Finally, the functional-programmatic classification makes it possible to identify the link between educational spending and its destination, provided through the different educational programs, functions and sub-functions of the agencies that make up the SEN. 


\section{Mexican National Education System}

According to Article 1 of the General Education Law (LGE) "the education provided by the State-Federation, States, Mexico City and municipalities, their decentralized agencies and individuals with authorization or with recognition of official validity of studies, is considered a public service" (Cámara de Diputados, 2019, p .1).

In the same sense, Article 5 of the LGE states that education "is a determining factor for the acquisition of significant knowledge and comprehensive training for the life of people with a sense of social belonging based on respect for diversity and is a fundamental means for the construction of an equitable and supportive society. " (Cámara de Diputados, 2019, p. 2).

Ontiveros (2001) mentions that education is a fundamental element for poverty reduction and efficient income distribution. In the short term, the provision of education can be understood as a redistribution of income because low-income families can have access to this service. Likewise, by having access to education, in the long term, human capital will be formed, allowing for better future economic opportunities, and reducing poverty levels.

Article 34 of the LGE states that the SEN is composed as follows (Cámara de Diputados, 2019, pp. 15-16):

- $\quad$ Learners.

- $\quad$ Teachers.

- Parents or guardians, as well as their associations.

Educational authorities.

School authorities.

Persons who have an employment relationship with the educational authorities in the provision of the public education service.
The educational institutions of the State and its decentralized agencies, the Systems and subsystems established in the Political Constitution of the United Mexican States, the present Law and other applicable provisions in educational matters.

- Private institutions with authorization or with recognition of official validity of studies.

- Institutions of higher education to which the law grants autonomy.

- Study plans and programs.

Movable and immovable property, services or facilities intended for the provision of public education services.

The School Participation Councils or their equivalents created pursuant to this Law.

School Committees for Participatory Management.

All actors involved in the provision of the public education service.

The Mexican education system is made up of three educational levels, these are Basic Education (EB), Higher Secondary Education (EMS) and Higher Education (ES), which, in turn, are divided and distributed under different modalities (García, 2016).

According to the Ministry of Public Education (SEP), basic education is defined as the "Systematic process of education comprising preschool instruction, in which some knowledge is imparted, and the formation of habits is stimulated; primary instruction, in which scientific knowledge and social disciplines are initiated; and, finally, secondary instruction, in which scientific knowledge is expanded and reaffirmed through observation, research and practice" (SEP, 2008, p. 87). 


\section{Quality in Basic Education}

Whether at national or international level a quality education is a very recurrent issue in public policy programs, due to the fact that, during the last few years there has been much debate on this issue, for which various tools have been developed to try to measure it, despite the different interpretations that this entails (Villa, 2016).

Santibáñez (2008) points out that education can have important effects through two channels. The first channel is to increase access; in this case, the impact is almost automatic because the greater the allocation of spending, the easier it will be to increase the supply of educational services and the easier it will be to contract them. The second channel is related to improving quality; however, this is more difficult to observe and quantify.

The National Institute for the Evaluation of Education (INEE) defines educational quality as "the quality that results from the integration of the dimensions of pertinence, relevance, internal effectiveness, external effectiveness, impact, sufficiency, efficiency and equity" (INEE, 2018 p. 5).

Among other things, INEE (2018) considers that for an education system to be considered of quality it must have the following characteristics:

- It has a curriculum that meets all the needs of the students and the society in which they reside, such as greater economic resources, development of science, attention to the environment, care and strengthening of cultural diversity, etc.

- $\quad$ Ensure that the majority of the school- age population has access to schools, and that they are provided with what they need to complete their studies and achieve their learning objectives.

- $\quad$ It ensures that the knowledge acquired by students is maintained over a long period of time and that this knowledge generates new social behaviors sustained by values, allowing them to develop as individuals and contribute to the development of society, allowing them to assume any role as full citizens.
$-$

To have the human and material capital necessary to provide the service and to make the best use of the resources invested.

- It takes into account the situation of the students and their families, and provides the necessary support based on their conditions so that the vast majority of students achieve their educational goals.

For the OECD (cited in Villa, 2016), quality in education refers to the certainty that all children and young people can obtain the knowledge, skills and competencies necessary for their growth for adult life, and that this allows them to contribute to the national economy and the development of society. This definition assumes that the higher the educational level of a person will generate a better economy and public health, however, it also assumes that people who do not achieve this growth in the long term generate a higher cost for the economy, security and health of the country. Therefore, it is imperative that the government provide students with the conditions and tools necessary for the development of their skills to meet the labor demand.

For UNICEF (cited in Villa, 2016) a quality education cannot be simplified to a single indicator as it is affected by various political, cultural and economic factors. Therefore, a true quality education includes:

- $\quad$ Students in good health, with a balanced diet and participation of their families and communities.

- $\quad$ Adequate learning places that allow for the development of students' skills.

- Relevant curriculum content to develop the basic skills and aptitudes to meet the labor demand.

- Student-centered teaching methods that facilitate learning and knowledge retention.

- That the lessons learned contribute to the achievement of the national objectives. 


\section{Measuring educational quality}

Villa (2016) tells us that in order to compare the level of educational quality in different countries, some tests have been created in order to standardize the results and allow their contrast at the international level. Many of these tests are conducted by the OECD to evaluate the different countries in basic subjects such as mathematics, natural sciences, reading and writing, etc.

Morales (2019) states that due to the importance of education in Mexico and educational reforms, evaluation is essential in order to improve public policies and programs for better decision making, contributing to better accountability and measurement of the efficiency of public spending in Mexico.

In addition, Villa (2016) tells us that there are several standardized tests used to measure the quality of education in different countries. The most common of these tests, and the one that will be analyzed in this article, is the Program for International Student Assessment (PISA). But we can also find the Program for International Assessment of Adult Competencies (PIAAC), or the Program for International Reading Literacy Study (PIRLS), a test that focuses mainly on the evaluation of the reading skills of students in different countries. Although these types of tests allow for correlation, they are not very sensitive to changes in curricula. Likewise, since these assessments are often multiple-choice, they can distort the results and therefore underestimate or overestimate the real learning obtained by students.

\section{PISA Test}

PISA is a wide-ranging harmonized assessment developed by the OECD. It refers to a project whose goal is to assess the level of knowledge possessed by students who have just completed their basic education, around the age of 15. It is carried out every 3 years and focuses on the assessment of 3 main subjects: reading, mathematics and scientific skills, with emphasis on the ability to control procedures, the understanding of concepts and the ability to act or function in various scenarios (OECD, n.d.).
Additionally, Villa (2016) indicates that another of the objectives sought through PISA is to contribute to decision making and relevant changes in public education policies, since showing student performance allows recognizing the current situation of the SEN and that it needs to be updated.

"Each exam is a combination of
straightforward questions with a single correct
answer, and questions that require students to
work out their own answers. Questions of the
first type can only be correct or incorrect, and
questions of the second type are more complex
to assess and admit partially correct answers."
(OECD, n.d., pp. 3-4).

The results of the last application of the PISA test in 2018 were published by the OECD on its official website on December 3rd, 2020, for analysis and interpretation by the public.

\section{Methodology}

The methodology used in this research, due to its characteristics, corresponds to a qualitative approach with an exploratory scope. In addition, it is documentary because the data were obtained through the review of various pages of institutions such as the National Institute of Educational Education (INEE), the Center for Economic and Budgetary Research (CIEP), the Organization for Economic Cooperation and Development (OECD), among others. Once the information was collected, we proceeded to data analysis with the purpose of observing the behavior of the variables studied and obtaining greater objectivity in relation to the objective and the premises set forth in this research.

\section{Analysis of Results}

This section will present the results of the PISA assessment applied to Mexican students in comparison with the evolution of the budget allocated to basic education (2015 - 2020).

\section{Evolution of Basic Education Spending}

As shown in Figure 1, we can see that during the last years Mexico has maintained a decreasing trend in the percentage of its budget as a part of GDP allocated to education, having slight increases during some years, but suffering a considerable reduction for the year 2020 from $3.7 \%$ to $3 \%$, decreasing almost one percentage point.

VILLAFAÑA-INFANTE, Luz María de Guadalupe, ISLASGONZÁLEZ, José Antonio and JIMÉNEZ-RICO, Artemio. Trends in public spending on basic education compared to the quality of education in Mexico. Journal of University Policies. 
Similarly, when we analyze the budget for basic education during the period 2015-2020 as a percentage of GDP, we can see that this percentage also suffers from a decreasing trend throughout these 5 years going from $2.3 \%$ for 2015 to $1.9 \%$ for 2020 , which meant a total decrease of almost half a percentage point.

These results are alarming since Mexico is moving further and further away from the general average of the countries that are part of the OECD, since this average represents $5 \%$ of the total GDP allocated to the education budget, therefore, Mexico now presents a figure that is 2 percentage points lower than the average of these countries. Finally, the expenditure allocated to basic education as a proportion of total education expenditure maintains a constant trend of increases and decreases, the most significant being $63.3 \%$ in 2020, which means a considerable reduction, losing more than 1 percentage point with respect to 2019 .

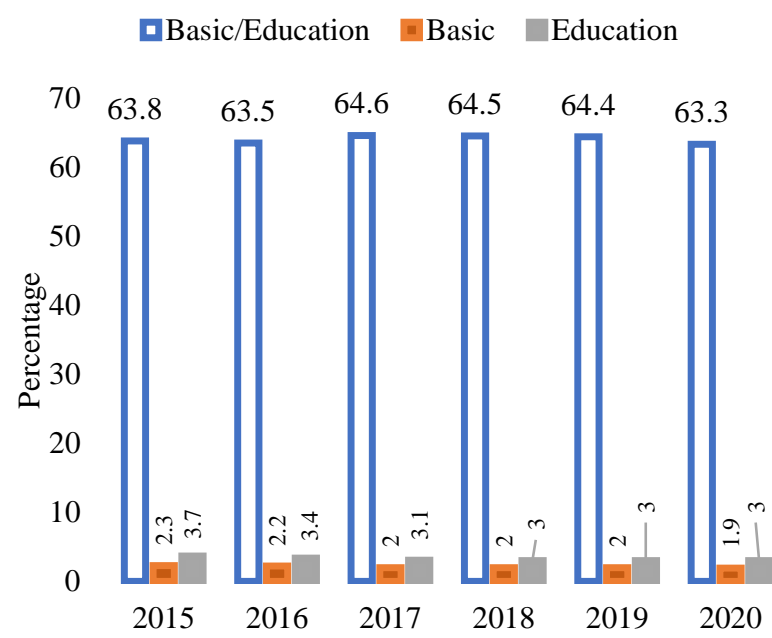

Figure 1 Education and Basic Education as a percentage of GDP 2015-2020

Source: Own elaboration [Excel] with data from INEGI and SHCP, PEF 2015-2019 and PPEF 2020 (cited in CEFP, 2019)

The Education function is divided into various sub-functions, among which we find the different educational levels of the SEN and other scientific research and development activities, sports, postgraduate studies and other educational services.
As shown in Figure 2, the sub-function with the highest percentage of public resources allocated corresponds to Basic Education, which represents $64 \%$ of the expenditure allocated to Education, with $17.2 \%$, Higher Education is the second sub-function with more resources allocated to its activities, and very close is the $13.3 \%$ allocated to Higher Secondary Education, leaving only $5.5 \%$ of the expenditure allocated to all other sub-functions that comprise the education function in Mexico.

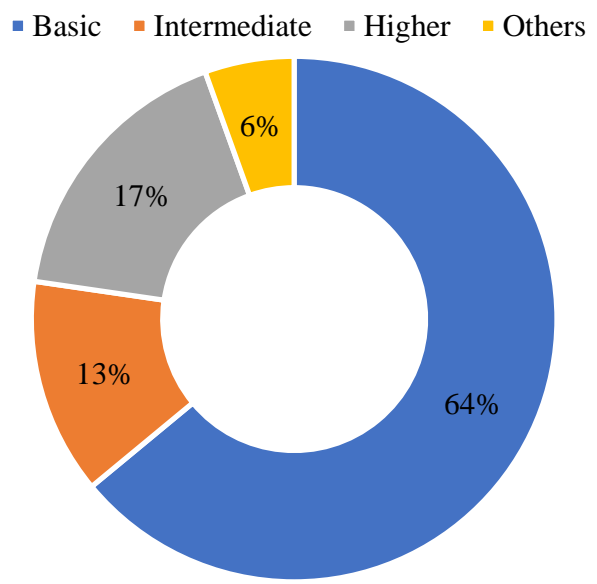

Figure 2 Education by Percentage Subfunction, 20152020

Source: Own elaboration [Excel] with data from SHCP, PEF 2015-2019 and PPEF 2020 (cited in CEFP, 2019)

The budget approved by the Ministry of Finance and Public Credit (SHCP) for Basic Education in the 2020 fiscal year totals the amount of $469,349.10$ mdp which at current prices represents a slightly higher amount than that of 2019, however, when converting the previous budgets to 2020 prices we observe that the real variation represents a decrease of $1.4 \%$, in addition it turns out to be the second lowest amount approved during this period only being slightly above the 2018 budget. Like the basic education budget as a percentage of GDP, this indicator presents a decreasing trend, only having a slight increase of $1.4 \%$ between 2018 and 2019, which is not enough to match the amount approved in 2015 representing a real annual average variation of $-2.1 \%$, which translates into fewer resources allocated to Education. 


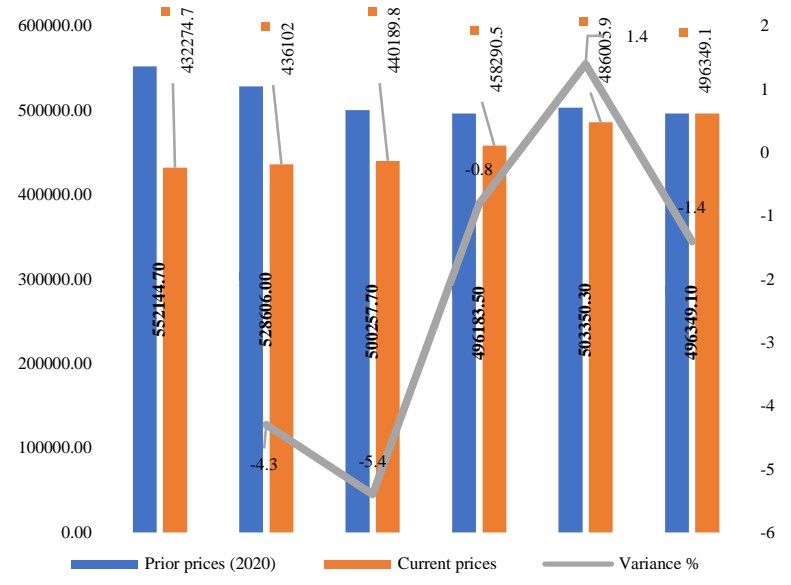

Figure 3 Basic Education Budget, 2015-2020 Source: Own elaboration [Excel] with data from SHCP, PEF 2015-2019 and PPEF 2020 (cited in CEFP, 2019)

\section{Education expenditure as a percentage of GDP}

When we talk about educational spending at the basic level in terms of \% of GDP in general, Mexico's situation seems very encouraging since its percentages from 2012 to 2017 have remained more or less the same, only presenting a decrease for 2017 , at the same time, these percentages have remained very similar to the percentages presented by the other OECD countries and being slightly above the OECD average. (See figure 4).

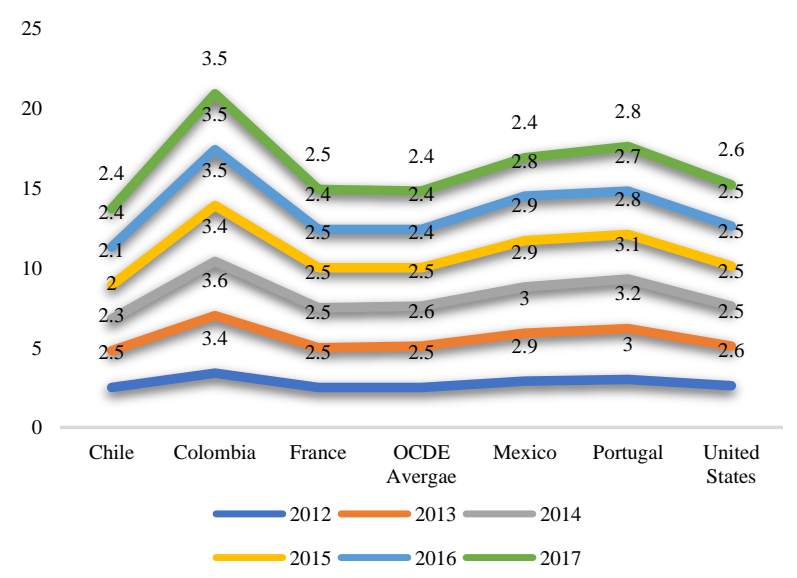

Figure 4 Spending on Basic Education as a percentage of GDP 2012-2018

Source: Own elaboration [Excel] with data from OECD (2020a)
However, when comparing educational spending in terms of GDP per capita allocated to each student we can notice a significant difference in Mexico (see figures 5 and 6), since while Mexico allocated 2.9\% of GDP in 2015, this only represented a GDP per capita of $16 \%$ for primary students and 14\% for secondary students, which is low compared to other OECD countries, such as Portugal, who invested in $20152.8 \%$ of its GDP, and had a GDP per capita of $25 \%$ for primary and $32 \%$ for secondary; another example, from Latin America, is Chile, which in 2015 its spending on basic education represented $2.1 \%$ of its GDP, and its GDP per capita represented $19 \%$ for primary and $20 \%$ for secondary.

These figures indicate that although the GDP invested by Mexico in educational spending at the basic level is above the OECD average GDP, it is not enough to cover the needs of the academic population that attends basic education in Mexico, since in none of the years analyzed in this research does our country fail to reach at least the OECD average of GDP per capita, which represents $21 \%$ for primary school students and $24 \%$ for secondary school students.

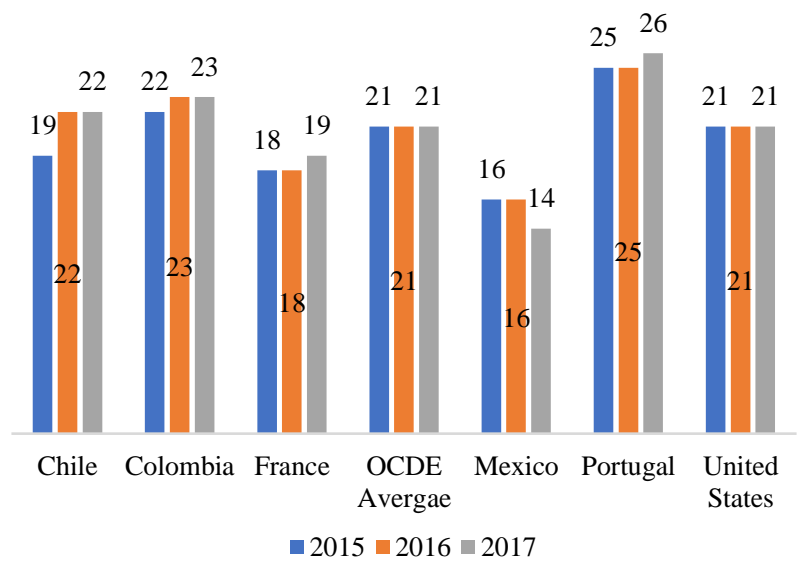

Figure 5 Primary Education Expenditure as a percentage of GDP per capita 2015-2017

Source: Own elaboration [Excel] with data from OECD (2020a) 


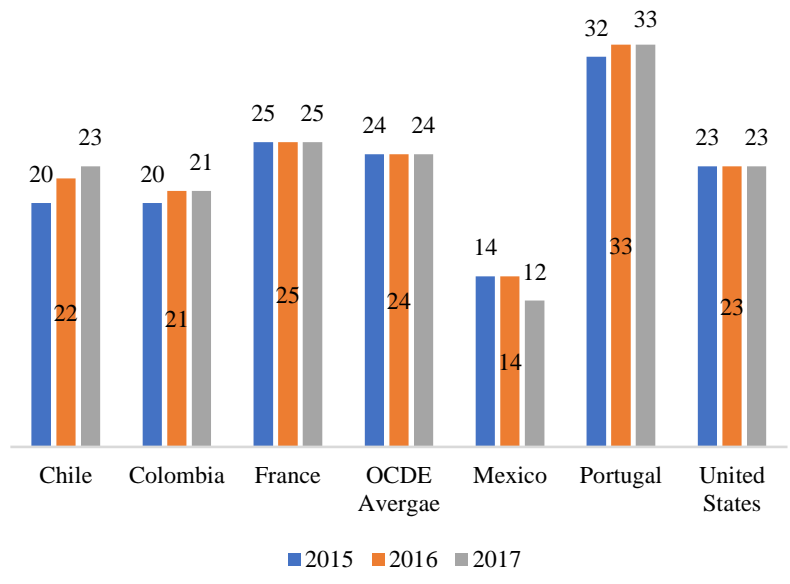

Figure 6 Secondary education spending as a percentage of GDP per capita 2015-2017

Source: Own elaboration [Excel] with data from OECD (2020a)

\section{Enrollment, Schools and Teachers}

According to the data offered in the First Government Report 2018-2019 we can appreciate the trend through the years of three very important aspects that make up education in all its levels, but for this case we will focus on the data regarding enrollment, schools and teachers within Basic Education. For the 20182019 period there was a slight decrease in enrollment of $2.76 \%$ compared to the 2014-2015 period, and a slight increase in the number of schools and teachers of $0.76 \%$ and $0.5 \%$ respectively compared to the 2014-2015 period. It is noteworthy to mark that despite the fact that facilities and teachers increased in small percentages through the years the number of students enrolled in the different levels of public education decreased, this could be due to various social or economic factors, such as the decrease in the population of age to attend this educational level or the lack of resources to communities with poverty rates due to cuts in the budget to education in recent years. Relating enrollment to the number of schools, there are 109 students per campus in 2019, which represents a not very significant difference compared to the 113 students per campus in 2015. In turn, doing a similar analysis, each teacher would be assigned groups of 20.82 students in 2019, which translates into a slight variation compared to the groups of 21.53 students corresponding to teachers in 2015. (See Figure 7).

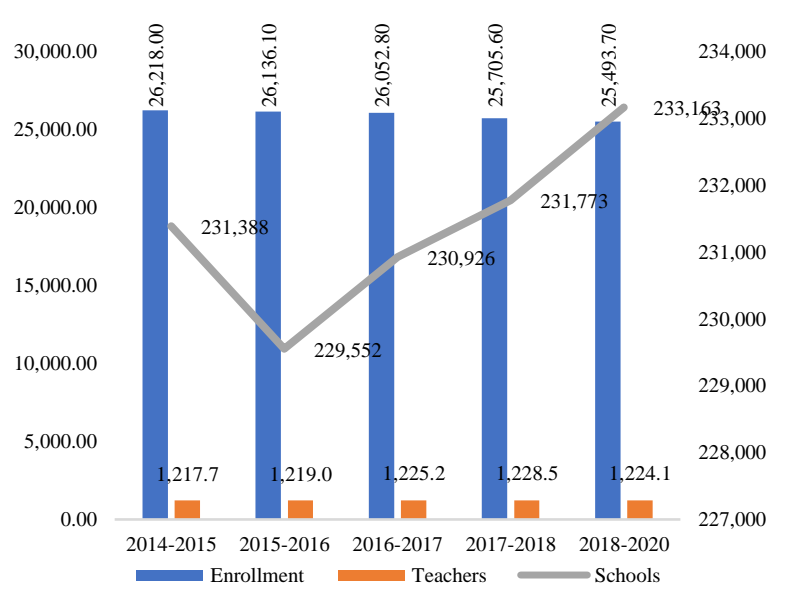

Figure 7 Enrollment, teachers, and schools in basic education. 2014-2019

Source: Own elaboration [Excel] with data from the 1st Government Report 2018-2019. Presidency of the Republic (2019)

\section{PISA 2018 Test Results}

The last PISA test applied was in 2018, and the results related to the test were published by the OECD on December 3, 2020.

Looking at Figures 8, 9 and 10, we can see that the reading, mathematics and science scores of Mexicans were below the average. These scores were 420, 409 and 419 respectively, while the OECD average scores were 487, 489 and 489.

If we compare it with Estonia and Indonesia, countries that positioned themselves in the test with the highest and lowest average, respectively, it can be seen that the average performance of students in Mexico ranks with the low-performing countries.

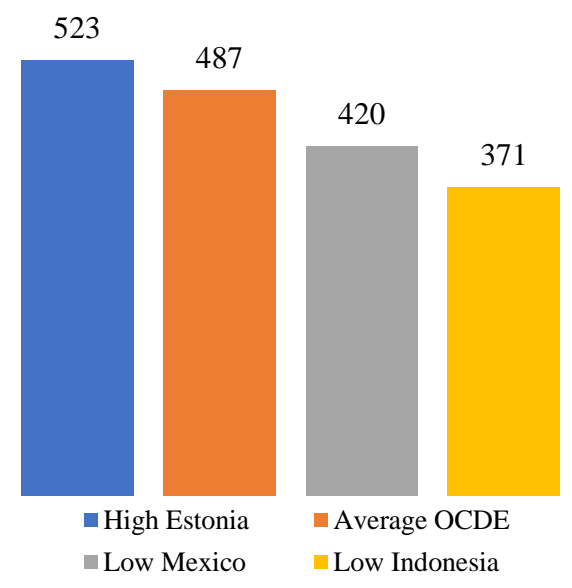

Figure 8 PISA 2018 Test Results, Reading Area Source: Own elaboration [Excel] with data from OECD (2020b) 


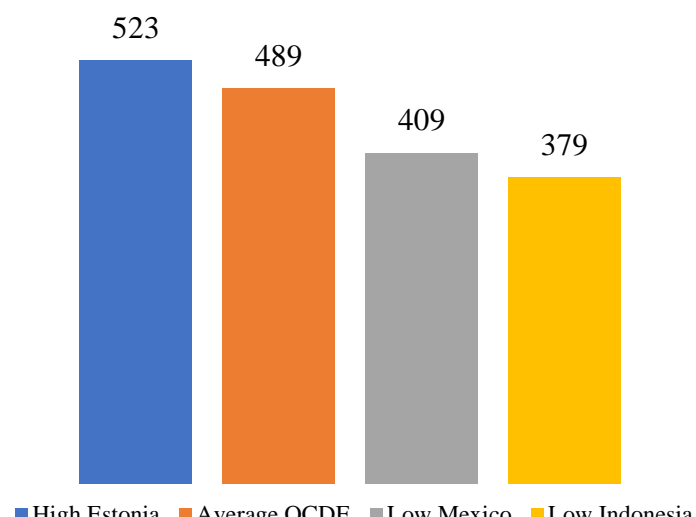

घigh Estonia $\square$ Average OCDE $\llbracket$ Low Mexico $\quad$ Low Indonesia

Figure 9 Pisa 2018 test results, mathematics area Source: Own elaboration [Excel] with data from OECD (2020c)

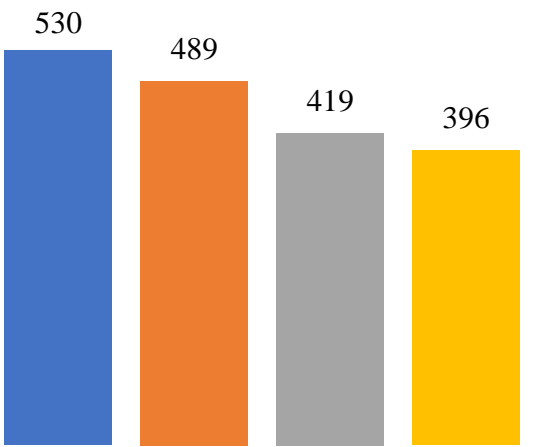

$\square$ High Estonia $\square$ Average OCDE $\square$ Low Mexico $\square$ Low Indonesia

Figure 10 PISA 2018 test results, science area Source: Own elaboration [Excel] with data from OECD (2020d)

Comparing the results of Mexico 2018 with the 2015 test, it was observed that there were small variations in the points of the different areas. In reading there was a drop of 3 points, while in mathematics there was an advance of one and in science three, indicating that there are no significant changes to determine an improvement or deterioration (see Figure 11).

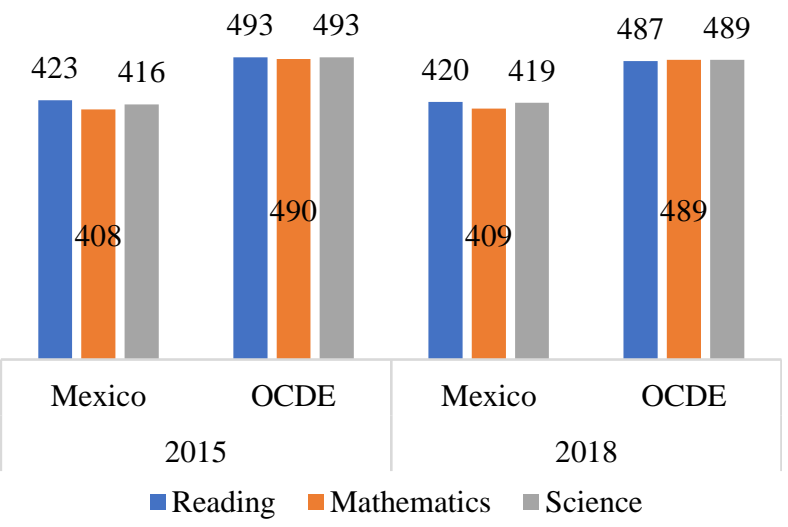

Figure 11 Mexico and OECD average results, PISA Test 2015 and 2018

Source: Own elaboration [Excel] with data from PISA 2015 Test, OECD (2016), Pisa 2018 Test, OECD (2019)

\section{What students know and can do in reading}

According to the analysis of the OECD's PISA 2018 test (2019), in Mexico, a little more than half of the students $55 \%$ reached at least a proficiency level 2 in the area of reading. This means that Mexicans according to information retrieval, locate one or more pieces of information which may include diverse criteria; for text interpretation, identify the main idea if it is of moderate length; and for reasoning and evaluation, manage to make comparisons or connections between the text and knowledge outside the text or explain a characteristic of the text by resorting to personal experience and attitudes.

On the other hand, about $1 \%$ of the students reached proficiency level 5, showing superior performance in reading. This means that, at this level, students retrieve information by inferring what is relevant to the task. They deal with highly plausible information or with conflicting alternatives; in the interpretation of texts, they can construct the meaning of a language with subtle nuances or demonstrate a full and detailed understanding of a text; and for reasoning and evaluation they do it critically by resorting to specialized knowledge, likewise, they handle uncommon concepts and show a deep understanding of long or complex texts.

In 20 education systems, including 15 OECD countries, more than $10 \%$ of students showed superior performance.

\section{What students know and can do in mathematics}

Likewise, with respect to the area of mathematics according to the OECD (2019), approximately $44 \%$ of students in Mexico reached proficiency level 2 in mathematics. This means that they can interpret and recognize situations in contexts that require only direct inferences. They can use basic algorithms, formulas, procedures or conventions. They can make use of direct reasoning and literal interpretations of results. On average in OECD countries, $76 \%$ of students obtained at least proficiency level 2 in mathematics. 
Only about $1 \%$ of students achieved a proficiency level of 5 or higher in mathematics. The highest proportion of this percentage were Asian students from countries such as China, Singapore and Korea. These students are able to achieve advanced mathematical reasoning and thinking.

\section{What students know and can do in science}

Finally, according to OECD (2019) data in the area of science it was observed that approximately $53 \%$ of Mexican students reached level 2 or higher in science. Students at this level can recognize the correct explanation for familiar scientific phenomena and can use such knowledge to identify, in simple cases, whether a conclusion is valid based on the data provided. Unfortunately, almost no students were able to position themselves at a level 5 or 6 demonstrating high proficiency in science. The few students who did achieve this level are able to apply their knowledge of science creatively and autonomously in a wide variety of situations, including unfamiliar situations.

\section{Trends in performance}

Mexico, being part of the countries belonging to the OECD group, has applied the PISA test from its first edition in 2000 to the last one applied in 2018. As can be seen in Figure 11, Mexico has maintained very similar results throughout all its participations in the evaluations of the 3 subjects. Being 425 the highest score for Reading in 2014, 419 the highest in Mathematics in 2009 and 419 as the highest for Science in 2018. However, despite the fact that the number of students eligible for the application of the PISA test has been increasing since 2003, in none of Mexico's participations in this assessment has it managed to reach the average of OECD countries, nor have there been significant improvements over the years.

The decreasing trend in the results of the last three evaluations corresponds to the periods in which the expenditure budget for basic education has decreased, which suggests a relationship between performance in the PISA evaluation and the amount of resources allocated to basic education, since although the decline in results is not so high, the reduction in the education budget is not so significant.
The reduction in the education budget has not been very high in percentage terms either, so this could mean that a significant reduction in the budget allocated to basic education will result in significantly worse performance in the PISA test than in the years when there was a better education budget.

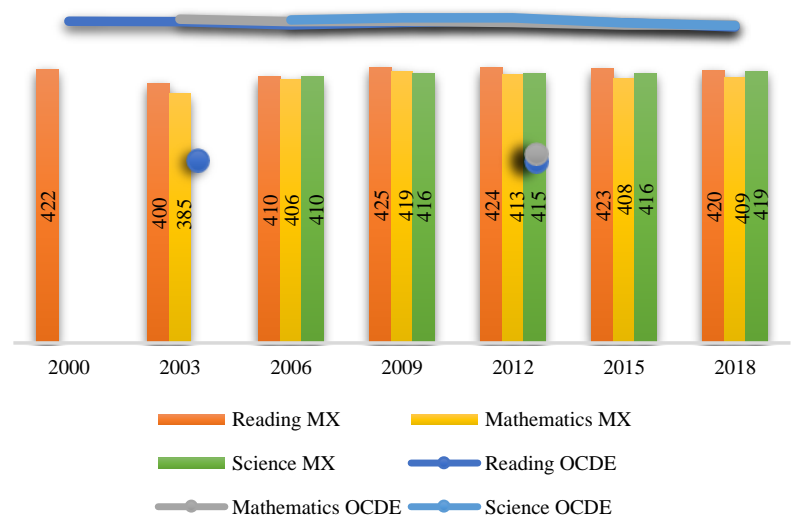

Figure 12 Trends in PISA test results 2000-2018 Source: Own elaboration [Excel] with data from PISA 2018 Test, OECD (2019)

\section{Conclusions}

Education represents a very important factor in the development of any country, since it is through this means by which the fundamental tools and knowledge that a professional must develop to improve the quality of life of his or her country are obtained. In Mexico this function represents $3 \%$ of GDP, suffering from a decreasing trend as of 2015, this figure represents 2 percentage points below the OECD average of $5 \%$ implying that in Mexico not enough is invested in this branch as other OECD countries do. Basic education is the initial basis of education and therefore a very important aspect that must be invested in for the development of future generations. In Mexico, this level of education represents $64 \%$ of total education spending. Although there have been increases in the budget over the last few years, these only represent a slight nominal increase since in terms of real variation from 2015 to 2020 the budget for Basic Education has suffered from a decreasing trend that represents an average annual variation of $-2.1 \%$.

This implied that currently this percentage only represents $2.4 \%$ of GDP, suffering from a decreasing trend since 2012, this figure represents an amount barely equal to the average of OECD countries. 
Unfortunately, when analyzed in terms of GDP per capita the budget allocated to basic education only represents $14 \%$ in primary education and $12 \%$ for secondary education, figures that are far below compared to other OECD countries, since the average is $21 \%$ and $24 \%$ respectively, and countries that invest the same or lower percentage of their GDP than Mexico have better results when converted into GDP per capita, these data mean that in Mexico not enough of the GDP is invested compared to the total population of basic education age.

A reflection of the above is that despite the increase in the number of institutions and professionals to provide the different levels of basic education, this has not represented an equitable increase in the enrollment of students in this sector; on the contrary, by 2019 enrollment represents $2.76 \%$ less than that of 2015.

The results of the latest PISA evaluations represent a decreasing pattern as well as that obtained from the analysis of the trends in the basic education budget (except for science, which had a small increase in 2018), since Mexico is among the countries that are considered low performers, as we went from a score of 425, 419 and 416 for Spanish, mathematics and science respectively in 2009 to 420,409 and 419 in 2018 respectively. It is worth highlighting that although Mexico has participated in all editions of the PISA test to date in no subject has it managed to reach the average of OECD countries.

Based on the above, the decreasing trend has affected in a similar proportion the results obtained in the last 3 PISA evaluations in which Mexico participated, corresponding to the years in which the trend of decreasing the budget for basic education began, which implies a correlation that gives us to understand that if the pattern continues in this way, the greater the budget reduction, the worse the performance of Mexican students in the following evaluations, this translates into an educational system that does not meet the necessary standards to be considered of quality in terms of the PISA test. Fortunately, this relationship also implies that as the budget increases, performance results and therefore the level of quality will also increase.
For the reasons stated above, the most important challenge to overcome is the correct distribution of the federal budget to education in general, since this will imply greater resources for basic education, but at the same time these must seek to satisfy the needs of its current population level and receive increases proportional to the increase in the population of the age to attend this educational level, since the decreasing trend in the budget for this level is also reflected in a negative trend in the results of the PISA test.

Finally, due to the decreasing trend of many of the indicators, it is essential that the competent authorities in Mexico design new policies capable of satisfying the needs of the new generations and that lead to an increase in the performance of young Mexicans in the PISA evaluations, and therefore increase the degree of educational quality in basic education.

\section{References}

Cámara de Diputados. (2019). Ley General de Educación publicada en el Diario Oficial de la Federación el 30 de septiembre de 2019. Recovered from: http://www.diputados.gob.mx/LeyesBiblio/pdf/ LGE_300919.pdf

Centro de Estudios de las Finanzas Públicas, CEFP. (2019), Presupuesto en Educación Básica 2015-2020 y Resultados de México en la Prueba PISA 2018. Recovered from: https://www.cefp.gob.mx/publicaciones/nota/20 19/notacefp0722019.pdf

García, F. (2016). El sistema educativo nacional y su financiamiento público (Informe CIEP Gasto Público para una Educación de Calidad). Recovered from: https://gastoeducativo.ciep.mx/Gasto-publicopara-una-educacion-de-calidad.pdf

Instituto Nacional para la Evaluación de la Educación, INEE. (2018). Definiciones de calidad de la educación en el Instituto Nacional para la Evaluación de la Educación. Recovered from: https://www.inee.edu.mx/definiciones-decalidad-de-la-educacion-en-el-institutonacional-para-la-evaluacion-de-la-educacion/ 
Martínez T. (2020). Gasto público en educación - PPEF 2021. Recovered from: https://ciep.mx/gasto-publico-en-educacionppef-2021

México, Presidencia de la Republica. (2019). 1 er Informe de Gobierno 2018-2019. Recovered from: $\quad$ https://lopezobrador.org.mx/wpcontent/uploads/2019/09/PRIMER-INFORMEDE-GOBIERNO.pdf

Morales, J. (2019). Evaluación del gasto público de la educación en México. Carta económica regional, 31(123), 121-157. Recovered from: https://biblat.unam.mx/es/revista/cartaeconomica-regional/articulo/evaluacion-delgasto-publico-de-la-educacion-en-mexico

Ontiveros, M. (2001). Gasto educativo y políticas distributivas de la educación primaria en México. Revista Latinoamericana de Estudios Educativos (México), 31(3), 53-77. Recovered from: https://www.redalyc.org/pdf/270/27031303.pdf

Organización para la Cooperación y el Desarrollo Económicos, OCDE. (2016). Programa para la Evaluación Internacional de Alumnos (PISA) PISA 2015 - Resultados. Recovered from: https://www.oecd.org/pisa/PISA-2015-MexicoESP.pdf

Organización para la Cooperación y el Desarrollo Económicos, OCDE. (2019). Programa para la Evaluación Internacional de Alumnos (PISA) PISA 2018 - Resultados. Recovered from: https://www.oecd.org/pisa/publications/PISA20 18_CN_MEX_Spanish.pdf

Organización para la Cooperación y el Desarrollo Económicos, OCDE. (2020a). Educational finance indicators - EAG 2020. Recovered from: https://stats.oecd.org/\#

Organización para la Cooperación y el Desarrollo Económicos, OCDE. (2020b). Reading performance (PISA). Recovered from: https://data.oecd.org/pisa/reading-performancepisa.htm\#indicator-chart
Organización para la Cooperación y el Desarrollo Económicos, OCDE. (2020c). Mathematics performance (PISA). Recovered from: https://data.oecd.org/pisa/mathematicsperformance-pisa.htm\#indicator-chart

Organización para la Cooperación y el Desarrollo Económicos, OCDE. (2020d). Science performance (PISA). Recuperado de https://data.oecd.org/pisa/science-performancepisa.htm\#indicator-chart

Organización para la Cooperación y el Desarrollo Económicos, OCDE. (s.f.). El programa PISA de la OCDE Qué es y para qué sirve. Recovered from: https://www.oecd.org/pisa/39730818.pdf

Santibáñez, L. (2008). El impacto del gasto sobre la calidad educativa. México: Programa de las Naciones Unidas para el Desarrollo. Recovered from: http://chamilo.cut.edu.mx:8080/chamilo/course s/POLITICASPUBLICASYEDUCACION23D EJU/document/4.-

_Financiamiento_de_la_educacion/2.-

El_impacto_del_gasto_sobre_la_calidad_educa tiva_2012.pdf

Secretaria de Educación Pública, SEP. (2008). Glosario. Términos utilizados en la Dirección General de Planeación y Programación 2008. Recovered from: http://cumplimientopef.sep.gob.mx/2010/Glosar io\%202008\%2024-jun-08.pdf

Villa, S. (2016). La calidad del sistema educativo Nacional (Informe CIEP - Gasto Público para una Educación de Calidad). Recovered from: https://gastoeducativo.ciep.mx/Gasto-publicopara-una-educacion-de-calidad.pdf 